\title{
Prometheus, Proteus, Pandora, and Procrustes Unbound: The Political Consequences of Reapportionment
}

\author{
Ward Elliott†
}

$[I] n$ those momentous days the French nation committed a deadly crime against democracy, which, on its knees, now utters the daily prayer: "Holy Universal Suffrage, pray for us!" Naturally enough, the believers in universal suffrage will not renounce their faith in a wonder-working power which has performed such great miracles on their behalf, which has transferred the second Bonaparte into a Napoleon, Saul into Paul, and Simon into Peter. The folk-spirit speaks to them through the ballot boxes as the god of the prophet Ezekiel spoke to the dry bones: "Haec dicit dominus deus ossibus suis: Ecce ego intromittam in vos Spiritum et vivetis."

-KarL MarX ${ }^{1}$

Citizens should be given the blessings of equality whether they want them or not.

-ANDREW HACKER ${ }^{2}$

\section{The Reapportionment Revolution Reconsidered}

With the Reapportionment Revolution now in its ninth year, it is possible to attempt a preliminary assessment of its political accomplishments. In 1962 it was conventional wisdom among the cognoscenti,

$\dagger$ Assistant Professor of Political Science, Claremont Men's College. This essay is taken from Chapter 6 of the author's forthcoming book Voting RIGHTS AND THE GUARDIAN ETHIC: SUPREME COURT INTERVENTION IN VOTING RIGHTS DISPUTES From TANEY TO WARREN. The author gratefully acknowledges the comments of Arthur Sutherland of the Harvard Law School, George Blair of the Claremont Graduate School, and my advisor, the late Robert McCloskey of the Harvard Government Department, whose passing has left a great gap in the profession and an even greater one with those of us who knew him. The essay was written under a grant from the Henry Salvatori Center, Claremont, Calif., but the author is solely responsible for its contents and opinions.

1 Marx's quote is from the first edition of his 18TH BrUMraIRE of Louls Bonaparte, deleted from subsequent editions but quoted in J. P. Mayer, ed., Introduction to THe RECOLLECTIONS OF ALEXIS DE TOCQUEville at XX-xxi (1949).

2 A. Hacker, Congressional Districting: The Issue of Equal Representation 120 (rev. ed. 1964). 
Gordon Baker, Anthony Lewis, Andrew Hacker, Robert McKay, John F. Kennedy, the Twentieth Century Fund, and the American Political Science Association, that Malapportionment ${ }^{3}$ was to blame for the worst problems of government at every level. It was supposed to have reduced city dwellers to second-class citizens, and to have stifled urgently needed reforms like home rule, slum clearance, metropolitan transit, annexation, labor and welfare legislation, civil rights laws, equal tax laws, and equal expenditures on schools and roads "because of the ignorance and indifference of rural legislators." Besides giving special powers to rural intransigents, Malapportionment was supposed to weaken federalism by splitting party control of legislatures and governorships, stopping government action and spawning "public cynicism, disillusionment, and apathy." Reapportionment was supposed to destroy the rural roadblock, unshackle the cities, unleash the bottled-up legislation, strengthen local and state representation, and produce a "new breed of legislator" as well."

Yet Prometheus unchained seems remarkably unchanged, either in the matter of banishing public cynicism, disillusionment, and apathy or of producing an urban tyranny, as Strom Thurmond had feared. Such changes as did take place seem more directly connected with political upheavals like the Democratic landslide of 1964 or the Republican gains of 1966-68 than with reapportionment. Studies by Andrew Hacker and the Congressional Quarterly based on pre-reapportionment data showed no connection between unequal districts and Congress' reluctance to pass liberal, administration-backed legislation. ${ }^{5}$ If anything, according to Hacker's weighting of sample roll calls, reapportionment could be expected to produce greater resistance to such measures. The most noted casualty of reapportionment in Congress was House Rules Committee Chairman Howard W. Smith, a conservative, who lost to his moderate opponent, George C. Rawlings, Jr., by 645 votes in the 1966 Virginia primary after his district had been redrawn. The net effect of this change was to introduce a New Breed of Congressman

3 Perhaps the greatest victory of the proponents of reapportionment was the public acceptance of the term "malapportionment" even by opponents of reapportionment. The term is handy, but loaded, describing all inequality of districts-which can be good or bad depending on its political context-as "bad apportionment." I have capitalized it in the hope of retaining the shorthand but warning against the implicit and gratuitous moral judgment.

4 See G. Baker, Rural Versus Urban Polmtical Power 4, 27-39 (1955); Twentieth Century Fund, ONe MAN-ONe Vote (1962); Lewis, Legislative Apportionment and the Federal Courts, 71 HARv. L. REv. 1057, 1063 (1958); Kennedy, The Shame of the States, N.Y. Times, May 18, 1958 (Magazine), at 12.

5 See 20 Cong. Q. Weekry Rep. 153-4 (Feb. 2, 1962); Cong. Q. Census Analysis, 1784-99 (Aug. 21, 1964); A. Hacker, Congressional Districting, supra note 2, at 97. 
in one district and that only with the help of a general trend toward new faces in Virginia politics, itself more connected with the revolt against the Byrd machine than with reapportionment. There was little change in the governance of the Rules Committee, since Smith was succeeded by another southern conservative, William M. Colmer of Mississippi.

In the states there were many changes, often quite dramatic ones, in regional control of legislatures, and some individual changes in policy in which reapportionment may have been a secondary factor; however, no overall trend of policy attributable to reapportionment can yet be perceived. On the basis of the Congressional Quarterly's August 1966 survey of reapportionment ${ }^{6}$ it seems reasonable to conclude that control shifted from one region to another in the legislatures of five states; Florida, where the fast-growing southern half of the state broke the northern half's traditional domination of the legislature after a bitter eighteen year struggle; Alabama, where power in the state senate was transferred from the agricultural south to the industrial north; Maryland, where the balance of power seemed to have shifted from the east shore, southern and western Maryland to the suburbs of Baltimore and Washington, and to Baltimore itself; California, where power shifted from north to south; and Nevada, where Reno and Las Vegas (and Howard Hughes?) now control the legislature formerly dominated by rural interests. In five western states with regionally apportioned senates-Arizona, Montana, New Mexico, Utah, and Missouri-reapportionment brought radical augmentation of urban power in one house. Gities in Vermont, Chicago, and the central Piedmont cities of North Carolina (Charlotte, Greensboro, Winston-Salem, and Raleigh) likewise gained substantially in their respective state senates. Georgia, Delaware, Texas, Kansas, Washington, and Michigan cities and suburbs made very substantial gains in both houses, such as to give them a good prospect of controlling the legislatures after the 1970 census if they do not control them already. Apart from these 19 states, reapportionment has not brought radical alterations in regional balances of power. Even in Tennessee, whose "crazy quilt" of unequal districts had inspired the Court to intervene in Baker $v$. Carr, ${ }^{7}$ the inequalities had been so haphazard that reapportionment does not seem to have brought about any major alterations in regional influence within the state.

Even where there were important changes in the balance of power, the New Breed of legislator looks more like Proteus than Prometheus,

6 Congressional Quarterly Background Report, Representation and ReapportionMENT passim, but especially 45-50, 62-93 (1966) (hereinafter cited as CQ).

7 369 U.S. 186, 254 (1962) (Clark, J. concurring). 
with new policies much less responsive to reapportionment than to other influences. In Michigan and Vermont, the New Breed followed George Romney and Philip Hoff; but in California it followed Ronald Reagan; in Florida it followed Claude Kirk; in Georgia, Lester Maddox; in Alabama, Lurleen Wallace. Can this be what Gordon Baker and the Twentieth Century Fund had in mind? After the Johnson landslide of 1964, reapportionists pointed to signs that the great breakthrough had come (although only five states had reapportioned in time for the 1964 elections). In Colorado, for example, though party control of the legislature was divided, counter to the reapportionists' script, the reapportioned legislature did appropriate more money for education, especially in Denver and suburbs, passed a dog leash law, an annexation law, a birth control law, and an abortion law; it provided for referenda on daylight savings and abolition of the death penalty, amid the usual reapportionist hoots that "the rural bloc' " had "sat on the lid too long." "8 The same kind of activity was going on all over the country, with reapportioned Vermont, ${ }^{9}$ Delaware, ${ }^{10}$ Michigan, ${ }^{11}$ and Iowa ${ }^{12}$ passing all sorts of welfare and civil rights legislation thitherto "bottled-up"-along with the unreapportioned United States Congress, which passed the Civil Rights Act of 1964 and the Voting Rights Act of 1965, both stalled under Kennedy, and the Málapportioned California legislature which had passed the Rumford Fair Housing Act in 1963 only to have it repealed by referendum in $1964 .{ }^{13}$ Negroes appeared in the reapportioned Georgia legislature in 1965 for the first time since 1907 and in Virginia and Alabama after the 1966 elections-but not in Mississippi, which lagged far behind the other southern states in registration of Negro voters. Hubert Humphrey spoke for almost all the experts when he told the National Legislators Leaders Conference that "Reapportionment has brought new life, new vigor to state government." 14

But was it reapportionment? Or was it that the conservatives had been walloped at the polls in 1964 and that 1965 was the Year of Civil Rights? Was it equal districts which brought the New Breed of legislator to Iowa and Colorado or the national Democratic landslide? Was

8 R. MCKay, ReApportionment: The LAW AND Polmtics of EQual Representation 268 (1965); see Dines, A Reapportioned State, 55 NAt. Crvic Rev. 70 (1966).

9 Bryan, Who is Legislating?, 56 Nat. Crvic Rev. 627 (1967).

10 McKAY, supra note 8 , at 269.

11 Id.; Note, Reapportionment, 79 HARv. L. REv. 1228, 1240 (1966).

$12 \mathrm{CQ}$ at $41-42$.

13 Proposition 14, which was the provision repealing the Rumford Act, was later declared unconstitutional as violative of the 14th Amendment's equal protection clause. Reitman v. Mulkey, 387 U.S. 369 (1967).

$14 \mathrm{CQ}$ at 41 . 
it the "Fundamental Principle of the Constitution"15 that revitalized federalism in Michigan and Vermont, or was it George Romney and Philip Hoff? Were the Negro legislators in Georgia and Alabama a product of redistricting or of doubled Negro registration since the 1950's. Public apathy, disillusionment, and cynicism indeed seemed much diminished in the states in the middle sixties, exactly as the reapportionists had foretold, but the suspicion waxed as the decade waned that the optimism of those days was a product of popular fashion, not the fruit of Reynolds $v$. Sims. ${ }^{16}$

Much cold water has flowed over the dam since the Year of Civil Rights. The Republican-conservative resurgence in the elections of 1966 replaced moderate Democratic governors like Pat Brown of California, Carl Sanders of Georgia, and Haydon Burns of Florida, with conservatives like Ronald Reagan, Lester Maddox, and Claude Kirk, while perpetuating the Wallace dynasty in Alabama. The Michigan legislature lost some of its lustre when some of the New Breed were charged with soliciting a Michigan State University coed for immoral purposes, repeated drunken driving arrests, wife-beating and nonpayment of federal income taxes. ${ }^{17}$ Senate Democratic leader Raymond D. Dzendzel of Detroit was criticized for accepting an electric wristwatch as a gift from a lobbyist after he steered a watchmaker's bill into law. ${ }^{18}$ California's first reapportioned legislature, though controlled by Democrats in both houses, cooperated with Republican Governor Ronald Reagan in slashing mental health expenditures and cutting back educational expansion. Colorado's second election of the New Era was "dull, uninspired, and ignored by large numbers of voters," 19 and it resulted, like many 1966 elections, in the ouster of many of the new Democrats of 1964. Reapportionists and others watching the cities for the expected Revitalization since reapportionment saw little sign of it; instead, every passing year seemed to show the cities and states less capable of dealing with their own problems; with the yoke of Malapportionment thrown off, the cities' political efflorescence expressed itself in riots and garbage strikes, and the New Federalism seemed to consist of appeals to the federal government for troops and money, if anything, more than the old.

National, state, and local elections in 1968 and 1969 continued the

15 "[T] fundamental principle of representative government in this country is one of equal representation for equal numbers of people. . . ." Reynolds v. Sims, 377 U.S. 533, 560-1 (1964).

16377 U.S. 533 (1964).

$17 \mathrm{CQ}$ at 41 .

$18 I d$.

19 McBride, The 1966 Election in Colorado, 20 WESTERN PoL. Q. 555 (1967). 
trend away from the civil rights euphoria of 1965, with the most dramatic rebuffs of the liberals taking place in the cities themselves. All three Presidential candidates in the 1968 campaign vowed to bring back law and order, with the winner, Richard Nixon, promising to bring back a Supreme Court of strict constructionists. The Republicans held onto their gains of 1966 in Congress and added to them in the states. In the cities conservative mayors like Sam Yorty of Los Angeles and Richard Daley of Chicago survived strong challenges from the liberals, while liberal mayors dropped like flies. Four liberal mayors, Joseph Barr of Pittsburgh, Jerome Cavanaugh of Detroit, Richard C. Lee of New Haven, and Arthur Naftalin of Minneapolis withdrew from electoral politics by their own choice. New York City liberals Robert Wagner and John Lindsay succumbed to lesser-known conservative rivals in their own party primaries. In Minneapolis moderate candidates of both parties lost to an ex-policeman, Charles Stenvig, running on the law and order ticket. George Wallace, surveying the New Breed of mayor, vintage 1968-69, was not wholly unjustified in claiming vindication in the cities of the hard-line conservatism he had pressed in the 1968 Presidential campaign. "My vote was only the tip of the iceberg," said Wallace. "There's others I'm responsible for: Stenvig, Mayor Yorty of Los Angeles, two mayoral candidates in New York. They were making Alabama speeches with a Minneapolis, Los Angeles and New York accent. The only thing they omitted was the drawl."20 The first four years since the great reapportionment of 1965-66 are a short basis on which to judge, but the swift change in the mood of government from the Year of Civil Rights to the Year of Law and Order has done very little to vindicate the experts of 1962.

Shortly after Reynolds $v$. Sims quantitative studies began to appear in the professional press, comparing indicators of Malapportionment in the various states with indicators of the various evils-suppression of party competition, split governments, inadequate welfare legislation, and budgetary discrimination against the cities-which Malapportionment was supposed to produce. ${ }^{21}$ Although these studies included the southern states, where all of these indicators except split governments

20 NEWSWEER, Oct. 6, 1969, at 65.

21 Jacob, The Consequences of Malapportionment: $A$ Note of Caution, 43 Soc. Forces 256 (1964); Dye, Malapportionment and Public Policy in the States, 27 J. PorrTics 586 (1965); Alvin D. Sokolow, After Reapportionment: Numbers or Policies? (1966) (unpublished manuscript on file with the author); Hofferbert, The Relation Between Public Policy and Some Structural and Environmental Variables in the American States, 60 Am. Por. Sci. Rev. 73 (1966); see D. Lockard, The Polmics of State and Local GOVERNMENT 319 (1963) (finding Massachusetts legislature with cities overrepresented no more responsive to urban needs than Connecticut, where cities were underrepresented). 
are common, they showed little sign of a relationship between Malapportionment and its claimed effects. The technique of the studies was to rank the states in order of Malapportionment prior to Baker $v$. Carr, then rank them according to level of party competition, frequency of divided government, distribution of state funds between urban and rural users, and level of expenditures for welfare, then see whether there was any relationship between the rank orders. Herbert Jacob tried three measurements of malapportionment: population ratio between the largest and smallest districts, Dauer-Kelsay scores of minimum population necessary to control a majority, and the David-Eisenberg index of "voting power" by county. ${ }^{22}$ Thomas Dye chose the Schubert-Press I index for his ranking of the states, allowing for skewness, kurtosis, and joint variability ${ }^{23}$ along with the Dauer-Kelsay and David-Eisenberg rankings. Richard I. Hofferbert chose the Schubert-Press II index, corrected for floterial districts as well as the other factors. ${ }^{24}$ These analysts picked different indicators for "liberal" welfare policies and budgetary favoritism, with Jacob relying on old age assistance, per capita health expenditures, and highway fund distribution, and Dye choosing school per-pupil expenditures, teacher's salary, teacher-pupil ratio (as well as welfare expenditures) and tax structure, while Hofferbert reckoned from per-pupil aid to local education, per-recipient aid to the aged, the blind, and the unemployed, per-family aid to dependent children, and direct state aid to the state's two largest cities. Alvin D. Sokolow used three derivatives of the David-Eisenberg index and chose highway and education grants and municipal annexation laws for his policy variables. Though the rank indicators of the different studies were not always the same, the results of comparison between policy ranking and apportionment ranking failed in almost every case to show a substantial connection between Malapportionment and its supposed policy results. California ranked fortieth on Hofferbert's apportionment scale, but third on his welfare orientation scale; Maine was seventh in apportionment but thirty-sixth in welfare. Only one of the five different standards of Malapportionment used showed any relationship with party competition ranking, and that was very low. ${ }^{25}$ None of the ap-

22 Jacob, Consequences of Malapportionment, supra note 21, at 257-8.

23 Dye, Malapportionment and Public Policy, supra note 21, at 588-90.

24 Hofferbert, Structural Variables, supra note 21, at 74. Schubert-Press I and II indices are from Schubert and Press, Measuring Malapportionment, 58 AM. Por. Scr. Rev. 302 (1964) (I), revised to correct for floterial districts, id. at 966-70 (II).

28 Dye, Malapportionment and Public Policy, supra note 21, at 594. Alvin D. Sokolow found urban underrepresentation "slightly to moderately" related to highway and education grants and municipal annexation laws, but found that the highway grant correlation, when corrected for road mileage, dropped "almost to 0." He also pointed out that the aid to education figures did not deal with a specific state policy but measured 
portionment scales showed a relationship between unequal districts and governments with split party control.

Neither these studies nor the experiences of the states since reapportionment prove the reapportionists wrong; the experience of the states has been very short, and the studies are limited by the clumsiness of their various standards of apportionment, by their inclusive aggregation of different political systems which are not wholly commensurable, and by their time frame, which was largely restricted to the decade just before Baker v. Carr. Better data and techniques of analysis might give a different picture for individual states and other times. But the available evidence seems more than sufficient to put the reapportionists' expectations of a great revitalization of state and local government into a more realistic perspective which should rank reapportionment as a trivial political influence compared to such traditional forces as parties, personalities, interest groups, and the perversities of popular fashion.

\section{REAPPORTIONMENT AND REPRESENTATIVE GOVERNMENT}

Now that the Reapportionment Revolution has been substantially won, reapportionists can afford to concede that they might have exaggerated a trifle in claiming that reapportionment would free the cities, liberalize policies, unplug bottlenecks in government, etc.; at least, they say, it has strengthened federalism and implemented the Fundamental Principle of the Constitution by securing equal representation for equal numbers. But has it? An honest answer would have to be yes, but no. Reapportionment has done a great deal to equalize representation in states like Florida, Alabama, California, Nevada, and Maryland, where unequal districts did disfranchise regions with population majorities; it has helped undermine white, one-party government

the amount of funds received by counties from a number of different sources for a number of different purposes. It was therefore not as meaningful as the other indicators. Sokolow, After Reapportionment, supra note 21, at Tables 1 \& 2. He did show, however, that five states with density and minimum mileage provisions in their aid to school transport scored only 50.2 average on the large county vote value index, while 15 states without these provisions (which limited state aid to city schools) scored an average of 73.5. Id. at Table 3. Allan G. Pulsipher and James L. Weatherby, in a 1968 study, used a regression model to correlate social and political data related to Malapportionment-apparently without controlling for the southern states-and concluded that within the "confining methodological procedure" chosen "it is possible to accept the hypotheses that malapportionment tends to depress and party competition tends to elevate some of the more important categories of state and local governmental expenditure."

"[W]e do feel strongly," they cautioned, "that a study much more ambitious than ours, or than those which have reached conclusions dissimilar to ours, is required before definitive answers to questions such as those we have explored ought to be offered." Pulsipher \& Weatherby, Malapportionment Party Competition, and the Function Distribution of Governmental Expenditures, 62 AM. PoL. Scr. REv. 1207, 1219 (1968). 
in the Deep South; it has corrected blatant discrimination against large sectors of the populations of a dozen or so states besides the five worst examples mentioned, and it has corrected more minor forms of discrimination in the rest of the country. But the Court has not made these corrections in a thoroughgoing or discerning way, except in the narrow sense of exacting strict adherence to its rule of equal districts as its best strategy for securing compliance without venturing into the quagmire. Because of the onesided and Procrustean character of the Court's intervention against Malapportionment, substantial questions remain as to whether the Reapportionment Revolution promoted equal representation in most of the states.

The Court's meddling with structural biases favoring one group or another was highly selective, for the best of tactical reasons: attacking the more subtle forms of structural discrimination would have raised the standards problem and landed the Court in the quagmire. The Court could abolish Malapportionment, which favored rural voters, but it could do nothing about bloc voting, multi-member districts, strategic majorities, and other structural biases which favored the cities. Nor could it reach gerrymanders except to make sure they were all the same size. In some cases this was an important restriction. In 1962, for example, Democrats in California and Republicans in Michigan and New York had successfully gerrymandered districts in their respective states; with stricter adherence to equal districts in New York, the Republicans picked up fewer extra seats. ${ }^{26}$ As a general rule, however, it appears that gerrymandering has been little hampered by having to work within equal districts. Robert J. Sickels examined ten congressional elections from 1946 to 1964 in states susceptible to gerrymandering; that is, with more than one district and a dominant party in the legislature with power to gerrymander. Comparing the votes received by the party with districting power with the median/mean average of its seats won, Sickels found that the power to gerrymander conveyed a striking advantage of 11 to 17 per cent extra seats. With 50 to 55 per cent of the total state congressional votes, the party with districting power won $67 / 69.8$ per cent of the seats; the party without districting power, also with 50 to 55 per cent of the total vote, won only $50 / 58$ per cent of the seats. ${ }^{27}$ No overall relationship could be found between equality of districts and effectiveness of the gerrymandering; in fact,

In the great majority of states with congressional gerryman-

2620 CONG. Q. WEERIY REP. 2163, 2165-7 (Nov. 16, 1962).

27 Sickels, Dragons, Bacon Strips, and Dumbbells-Who's Afraid of Reapportionment?, 75 YALE L.J. 1300, 1303 (1966); double figures are median/mean percentages of seats won. 
ders, unequal district size either has not affected the gerrymander or has made it less effective than it would have been had the districts been equal. ${ }^{28}$

\section{A GerRymandering Revolution?}

How can one explain Sickels' findings? Two theories come at once to mind: a gerrymander, to be effective, must be kept up to date, and nothing offers itself so readily to redrawing gerrymanders as reapportionment. The same population shifts which caused unequal districts could also render the most skillfully drawn gerrymander obsolete. Yet in normal circumstances legislators prefer stable districts and safe seats to districts which are constantly being redrawn to follow population shifts, no matter whether the redrawing is intended to equalize the districts or to maximize the power of one party or one interest. The balance of political motives in most legislatures frustrated radical redistricting of any kind; wedded to the status quo, it frustrated reapportionment and gerrymandering alike.

Radical reapportionment overrides a legislature's instinct for leaving the districts alone yet leaves unchecked the normal disposition of legislators to consult their own interests. A majority party which is compelled to redraw its districts can be expected to draw them to its own advantage, as minority parties and groups across the country found to their discomfiture, for there is every reason to believe that the Reapportionment Revolution brought with it something which none of the experts had thought of-a Gerrymandering Revolution. Perhaps the most striking indicator of gerrymandering in the course of reapportionment was the profusion of grotesque districts which the mapmakers of the 1960's left behind. Texas legislators set up a district 250 miles long and one county wide for much of its length for Congressman Olin E. Teague. ${ }^{29}$ Colorado's Fourth Congressional District stretched 400 miles diagonally across the state from the Nebraska border in the northeast to the southwestern tip of the state where it borders Utah, Arizona, and New Mexico. ${ }^{30}$ New York's 148th Assembly District was 43 miles long, taking a slice of Rochester, continuing through the towns of Greece, Parma, and Hamlin, and then stretching 24 miles into Orleans County; the 153d District was laid out in two sections separated by three towns and two other districts. ${ }^{31} \mathrm{~A}$ three-judge federal court invalidated New York's congressional apportionment of 1961, describ-

28 Id. at 1300.

20 N.Y. Times, May 25, 1967, at 3 (city ed.).

$30 \mathrm{CQ}$ at 87.

31 In re Orans Petition, 45 Misc. 2d. 616, 652, 257 N.Y.S.2d 839, 873 (Sup. Ct. 1965). 
ing the wild contortions of four Brooklyn districts as "bizarre."32 A North Carolina federal court invalidated a congressional apportionment plan whose districts varied no more than 8.9 per cent from average because of the "tortuous lines" of districts drawn to protect incumbents. ${ }^{33}$

Cities and urban minority groups who had hoped to profit from reapportionment found themselves instead cut to pieces and tacked on to districts of different political makeup. In Texas, Dallas-Fort Worth and San Antonio were divided into eight districts, four of which were tied to expanded rural districts. ${ }^{34}$ Memphis, ${ }^{35}$ Kansas City, Kansas, ${ }^{36}$ Wichita $^{37}$ Oklahoma City, ${ }^{38}$ and Newark ${ }^{39}$ were likewise dismembered. Elizabeth, the county seat of Union County, New Jersey, was detached and joined to Hudson County on the other side of Newark Bay. ${ }^{40}$ Negro communities in Boston and New York City were divided and the pieces parceled out to districts with white majorities; ${ }^{41}$ urban Negroes in Georgia, Tennessee, and Virginia protested their submersion in specially created multi-member districts. ${ }^{42}$ Partisan minorities in Hawaii, ${ }^{43}$ Iowa, ${ }^{44}$ New Mexico, ${ }^{45}$ and Pennsylvania ${ }^{46}$ also complained of submersion in multi-member districts or at-large elections.

The reader should be extremely suspicious of a bare listing of distorted districts and constituents' complaints to support the theory that reapportionment has brought with it a wave of gerrymandering. Reapportionists used just such isolated and subjective evidence to support their dubious doctrine of the rural roadblock, and it has not held up well under closer examination. A better case for a connection, whether positive or negative, between reapportionment and gerrymandering would require techniques like those of Robert Sickels, comparing the ratio of votes won to seats won by parties with and without districting power, in elections before and after reapportionment..77 If one could

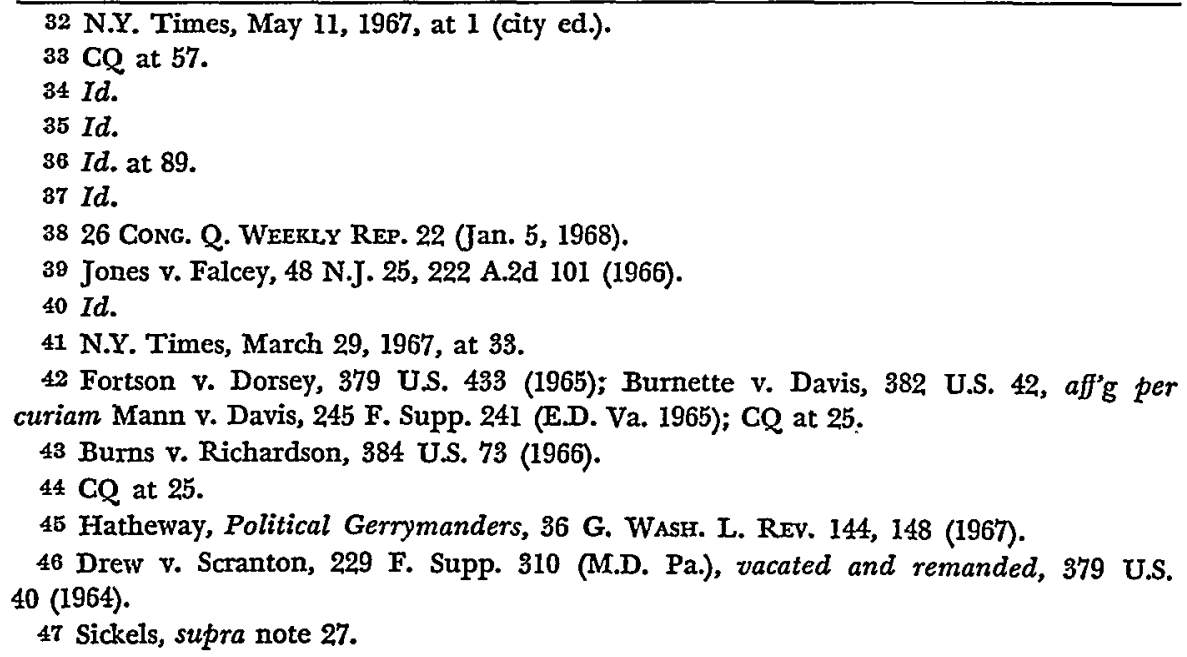


show that parties controlling reapportionment won more seats per vote than parties that did not, one could have a substantial indicator of the overall effectiveness of the power to gerrymander since reapportionment; the results could then be compared with those of pre-reapportionment elections to see whether reapportionment has encouraged or discouraged effective gerrymandering-though even this kind of examination would show very little about racial, ethnic, and other forms of nonparty gerrymandering.

Ideally, such a study would be addressed to state legislatures and cover several elections since reapportionment to avoid sampling error. Although detailed information on federal Congressional elections is much easier to get than information on state elections, federal elections involve fewer districts than state elections and are more likely to produce sampling error. Moreover, Congressional districts have always been subject to an external inter-state reapportionment requirement under article $I$, section $2,{ }^{48}$ which may obscure the effects of the intrastate reapportionment requirement of Wesberry $v$. Sanders. ${ }^{48}$ Unfortunately, however, the states do not usually circulate detailed election results, and at this writing ${ }^{50}$ few of them have had more than two or three post-apportionment elections.

The returns of the 1966 and 1968 Congressional elections, however, suggest very strongly that parties with reapportionment power have used it to enormous advantage. In Kansas' 1965 reapportionment, for instance, the Republicans were ordered to redraw district boundaries to equalize the districts. They saw no reason not to draw the new boundaries to their own advantage and therefore split Sedgwick and Wyandotte Counties (Wichita and Kansas City) in two to strengthen their hold on two otherwise competitive districts. ${ }^{51}$ By so doing, they were able to win four out of Kansas' five seats in Congress: 80 per cent of the seats for only 57.3 per cent of the vote, for a winner's extra margin of 22.7 per cent. By contrast, Oregon Republicans, who had 51.7 per cent of the popular vote but had not controlled the districting, won only two of Oregon's four seats for a popular winner's margin of minus 1.7 per cent. A similar contrast may be drawn between North Carolina and Minnesota. North Garolina Democrats controlled the districting in 1966 and won 72.7 per cent of the seats with 59 per cent of the votes in 1966, a winner's margin of 13.7 per cent. Minnesota Democrats did not control the districting of 1961. In 1966, with 50.1 per cent of the

48 "Representatives . . . shall be apportioned among the several States . . ." U.S. CoNsT. art. I, § 2.

49376 U.S. 1 (1964).

50 Early 1970.

5124 CoNg. Q. WeEkLy REP. 2049 (Sept. 16, 1966). The Republicans swept all five Kansas congressional districts in the 1966 and 1968 elections. 
votes, they won only 38 per cent of the seats, a margin of minus 12.1 per cent.

If these examples were representative, they would indicate that the power to gerrymander gave its possessor a crushing 25 per cent advantage over nonpossessors who were also able to secure popular majorities. However, such examples are not necessarily representative, for a number of reasons. They are drawn from elections of a single year, 1966; they are taken from comparatively small states; and the figures for North Carolina and Minnesota are distorted by uncontested districts. Even Kansas and Oregon might have come out as they did whether there was gerrymandering or not; the samples of five and four seats in one election are too small to be free of the vagaries of their political surroundings. One of Minnesota's eight districts and two of North Carolina's eleven districts had unopposed candidates; the figures given here are based on the unrealistic assumption that the unopposed party had "won" 100 per cent of the votes in the district. In states like Texas, where 13 of 23 candidates ran unopposed in 1966, it is not possible to do anything but guess the political impact of gerrymanders-a serious obstacle to overall assessment, because such states are probably more thoroughly gerrymandered than states where the districts are all contested.

A good sample, however, must be tolerably commensurable with its universe, and large enough to be representative. It would have to exclude cases where more than one or two seats were uncontested, and it would have to cancel out the vagaries of local and temporary factors either by covering several elections or by confining itself to large states, whose many districts would tend to cancel out local factors. A large sample of elections will not be available until more elections have been held; i.e., in the 1970's. However, it is still possible to examine the experience of large, widely contested states, in the congressional elections of 1966 and 1968, and these suggest that parties with districting power have used it to their own advantage with devastating effect. The fate of the Republicans in California and Pennsylvania in 1966, who respectively won 44.7 and 48 per cent of the seats with 51.8 per cent and 51.5 per cent of the votes, stands in sharp contrast with that of the Democrats in Missouri in 1966, who won 80 per cent of the seats with only 55.9 per cent of the votes. Table One suggests that in the large states the districting power conferred on its possessor an advantage of 18.8 per cent extra seats in the 1966 and 1968 elections-larger than the average of 11 to 17 per cent extra seats which Robert Sickels found for the elections from 1946 to $1964 . .^{52}$

52 Note, however, that the basis of the 18.8 figure for the 1966 and 1968 elections is 
TABLE ONE

Votes Gast and Seats Won in LaRge Contested States, 1

Congressional ELECTIONS OF 1966 AND 1968

\begin{tabular}{|c|c|c|c|c|c|}
\hline $\begin{array}{c}\text { State/ } \\
\text { Election Year }\end{array}$ & $\begin{array}{l}\text { Districting } \\
\text { Date }\end{array}$ & $\begin{array}{l}\text { Number } \\
\text { Districts }\end{array}$ & $\begin{array}{c}\text { Votes Won } \\
(\%)^{2}\end{array}$ & $\begin{array}{l}\text { Seats Won } \\
(\%)\end{array}$ & $\begin{array}{c}\text { Bonus } \\
(\%)\end{array}$ \\
\hline \multicolumn{6}{|c|}{ Winner controlled districting: } \\
\hline Ind. 68 & 19683 & 11 & $53.2(53.7) \mathrm{R}$ & 68.6 & $10.4(9.9)$ \\
\hline Mich. 66 & 1964 & 19 & $50.0(49.8) \mathrm{R}$ & 63.2 & $13.2(13.4)$ \\
\hline Mo. 66 & 1965 & 10 & $55.9(53.6) \mathrm{D}$ & 80.0 & $24.1(26.4)$ \\
\hline Mo. 68 & 1967 & 10 & $56.9(56.0) \mathrm{D}$ & 90.0 & $83.1(34.0)$ \\
\hline N. J. 66 & 1966 & 15 & $50.0(50.5) \mathrm{R}$ & 60.0 & $10.0(9.5)$ \\
\hline N. J. 68 & $1967 / 685$ & 15 & 52.9 (49.2)D & 60.0 & 7.1 (11.8) \\
\hline Ohio 66 & 1964 & 24 & $57.1^{4}(56.1) \mathrm{R}$ & 79.2 & 22.1 (23.1) \\
\hline Ohio 68 & 1968 & 24 & $60.3(60.8) \mathrm{R}$ & 75.0 & 14.7 (14.2) \\
\hline Pa. 68 & 1966 & 27 & $51.9(53.5) \mathrm{D}$ & 51.9 & $0.0(-1.6)$ \\
\hline Wis. 66 & 1963 & 10 & $52.7(53.8) \mathrm{R}$ & 70.0 & $17.3(16.2)$ \\
\hline \multirow[t]{2}{*}{ Wis. 68} & 1963 & 10 & $53.8(54.4) \mathrm{R}$ & 70.0 & $16.2(15.6)$ \\
\hline & & & & \multicolumn{2}{|c|}{ Average bonus: $\overline{14.7} \overline{(17.1)}$} \\
\hline \multicolumn{6}{|c|}{ Winner did not control districting: } \\
\hline Calif. 66 & 1961 & 38 & $51.8(53.3) \mathrm{R}$ & 44.7 & $-7.1(-8.6)$ \\
\hline Calif. 68 & 1968 & 38 & $52.9(55.0) \mathrm{R}$ & 44.7 & $-8.2(-10.3)$ \\
\hline Ill. 66 & I9653 & 24 & $53.3(54.2) \mathrm{R}$ & 50.0 & $-3.3(-4.2)$ \\
\hline Ill. 68 & 1965 & 24 & $51.5(53.6) \mathrm{R}$ & 50.0 & $-1.5(-3.6)$ \\
\hline Ind. 66 & 1965 & 11 & $56.8(53.5) \mathrm{R}$ & 54.5 & $-2.3(1.0)$ \\
\hline Mich. 68 & 1964 & 19 & $52.3(49.1) \mathrm{R}$ & 36.8 & $-15.5(-12.3)$ \\
\hline N. Y. 66 & 1961 & 41 & $56.1(52.5) \mathrm{D}$ & 63.4 & $7.3(10.9)$ \\
\hline N. Y. 68 & 1968 & 41 & $55.6(52.3) \mathrm{D}$ & 61.0 & $5.4(8.7)$ \\
\hline \multirow[t]{2}{*}{ Pa. 66} & 1966 & 27 & $51.5(49.5) \mathrm{R}$ & 48.1 & $-3.4(-1.4)$ \\
\hline & & & & \multicolumn{2}{|c|}{$\begin{array}{r}\text { Average bonus: }-4.1(-2.2) \\
(18.8 \%)(19.3 \%)\end{array}$} \\
\hline
\end{tabular}

Average extra margin from districting control: $18.8 \%$ of seats (19.3\%).

1 Excludes all states with less than ten districts or more than one district unopposed.

2 Percentage is of two-party vote, computed by adding and averaging the percentages in each district. Figures in parentheses are computed by adding the actual votes won by each party.

3 Indiana and Illinois were districted by federal courts with 2-1 partisan majorities.

4 One candidate was unopposed and is credited with $100 \%$ support in his district.

5 New Jersey was redistricted by the Democrats in 1967; the Republicans altered two of the 15 districts for the 1968 elections.

not commensurable with Sickels' basis for the 1946-64 elections. Sickels excluded all elections where any district was uncontested and all elections where one party won more than $55 \%$ of the popular vote; his mean margin of advantage for all contested elections in all states was $11.8 \%$, median margin, $17.0 \%$. For states of ten or more districts, all districts contested, the mean margin of advantage was $16.9 \%$, median, $14.5 \%$. Sickels, supra note 27, at 1302-3. If Ohio, Missouri, New York, and Indiana in 1966 were excluded from the elections in Table One, thereby making every district in the remaining states contested, the basis of the margin of advantage in the large states would be the same as Sickels', but the resulting 1966 and 1968 mean margin-17.1\%-would still be a hair larger than that of the earlier elections- $-16.9 \%$. 
Table One includes only ten of the large states with contested districts; however, these ten states comprise half the seats in Congress, 219 out of 435. Another six states with ten or more districts, but with more than one district uncontested, account for another 75 seats; ;3 $^{63}$ states with nine districts or less comprise the remaining 141 seats. Perhaps time and a detailed examination of elections for state legislatures will give firmer ground for assessing the gerrymandering consequences of reapportionment, but it is safe to say that party cartographers were never so busy as they have been since reapportionment, ${ }^{54}$ and the little firm evidence we have suggests very strongly that they redrew the new districts to party specifications.

\section{Effect on Party and Negro Power}

The concurrence of the Gerrymandering Revolution with the Reapportionment Revolution has tempered earlier predictions that reapportionment would increase Republican and Negro representation by favoring cities in the South and suburbs across the nation. Preliminary investigations by Andrew Hacker, the Republican National Committee, and the Legislative Reference Service concluded that Republicans and Negroes stood to gain from reapportionment, which would give more votes to their strongholds in southern cities and to suburbs across the nation where Republicans were strongest, provided districts were drawn at random. ${ }^{55}$ However, except in some of the minority of states with non-legislative redistricting, ${ }^{56}$ it has not been the tradition to redistrict

53 These states are: Florida (12 seats); Georgia (10); Massachusetts (12); North Carolina (11); Texas (20); and Virginia (10).

64 All the states but Oregon have had some kind of redistricting since Baker $v$. Carr. Some states have gone through repeated redistricting as parties struggled to replace each other's gerrymanders with their own. Thus, Missouri redistricted in 1961, 1965, and 1967; New Jersey in 1961, 1966, and 1968, with each redistricting battle diverting the legislators' attention from more substantive matters.

65 Cong. Q. Census ANALysis 1786 (Aug. 21, 1964); U.S. Library of Congress, Legislative Reference Service, Recent Supreane Court Decisions on Apportionment: Their Political IMPACr 11-12, 22-23 (1964).

56 Only six states-Alaska, Arizona, Arkansas, Hawaii, Missouri, and Ohio-had nonlegislative reapportionment in 1962; seven others-California, Illinois, Michigan, North Dakota, Oregon, South Dakota, and Texas-provided for nonlegislative apportionment if the legislature failed to act within a specified time. Seven states-Alaska, Arkansas, Hawaii, New York, Oklahoma, Oregon, and Texas-provided for court review of apportionment plans. Advisory Commisston on Intergovernmental ReLATIONS, ApPortionment OF STATE Legislatures 21-22 (1962).

See CQ at 48-50 for a description of the three-year fight in Illinois over which "nonpartisan" body-the United States District Court in Chicago (with two Democratic judges and one Republican), or the State Supreme Court (Republican, 5-2), or the senate redistricting commission-should redistrict. Most of the issues were eventually settled by compromise between the parties themselves. Three-judge federal courts in Indiana 
at random, but to redistrict to the advantage of whoever conducted the redistricting, which may explain Senator Dirksen's interest in stopping it. The Reapportionment Revolution took place at a particularly bad time for the Republicans; namely, after the elections of 1964, which had cost the Republicans 101 seats in state senates and 426 seats in state houses of representatives. Only a handful of states had reapportioned in time for the 1964 elections; ${ }^{57} 39$ states reapportioned in 1965 and 1966 when the Democrats controlled both houses in 32 states, the Republicans in only six, with control split in eight states.88 "The result," concluded the Congressional Quarterly, in 1966, "may be a built-in Democratic advantage . . . for years to come." 59 The 1966 California elections, where the Democrats retained majorities in both houses and in the state's delegation of United States Congressmen though outpolled by the Republicans by substantial margins in all three elections, ${ }^{60}$ show how reapportionment, combined with gerrymandering, took away in practice the equal representation it purported to convey on paper.

Although Negroes probably gained overall from reapportionment in the South, they also suffered no less than other local minorities from constitutionally decent burial in multi-member districts, which shared in the general efflorescence of discriminatory districting. Georgia, Virginia, and Tennessee Negroes found their hopes of electing Negro delegates swallowed in part by the mapmaker's dragon, but they appealed in vain to the Supreme Court and state courts, whose rulemaking resources were not equal to dealing with such tasks. ${ }^{61}$ Other minorities were likewise buried without hope of judicial rescue, ${ }^{62}$ though in most

and Missouri dutifully rendered judgments in 1967-68 redistricting cases in strict accord with the party background of the judges. Republicans called for a Congressional investigation when District Court Judge John W. Oliver, a long-time Democrat, consulted with Democratic Governor Warren E. Hearnes prior to rendering the Court's decision. 26 CONG. Q. WEERLY REP. 488 (Mar. 8, 1968).

57 Note, Reapportionment, 79 HARV. L. Rev. 1226, 1239 (1966); CQ at 68-69.

$58 \mathrm{CQ}$ at 59,69. The Republicans had lost control of both houses in six states, one house in another seven states.

59 Id. at 44.

60 See Anderson and Lee, The 1966 Election in California, 20 WEstern Por. Q. 535, 551 (1967). The effect of the California gerrymandering was to create so many safe seats that California politics are more and more centered in party primaries, as in the South. "In all three chambers-Senate, Assembly, and House of Representatives-well over half the seats are so heavily registered for one party or the other that general election competition offers little promise of success." Id.

61 Lucas, Of Ducks and Drakes: Judicial Relief in Reapportionment Cases, 38 NOTRE DAME LAW. 401 (1963).

62 See, e.g., Fortson v. Dorsey, 379 U.S. 433 (1965); Burnette v. Davis, 382 U.S. 42 (1965); Burns v. Richardson, 384 U.S. 73 (1966); Drew v. Scranton, 229 F. Supp. 310 (M.D. Pa.), vacated and remanded, 379 U.S. 40 (1964); $\mathrm{CQ}$ at 25. But see Fairley v. Patterson, 393 U.S. 544 (1969). 
cases the discriminatory districts had been created under the judicially sponsored pressure of reapportionment.

Unlike its pre-reapportionment forebears, the New Breed of gerrymander and multi-member district cannot be expected to weaken with time and population changes in fulfilling its discriminatory function, for the districts must be redrawn according to the Fundamental Principle at least once every ten years in a fresh Reapportionment Revolution whose equal districts can be expected to discriminate in favor of those holding power in the early 1970's and 1980's as they now discriminate in favor of those who hold power in 1965 and 1966.63 The Reapportionment Revolution appears to have brought with it more and better gerrymanders, and it can be expected to go on doing so in the future as long as the district system is there to provide the motivation to keep discrimination up-to-date.

\section{V. "NonPartisan" Districting}

A theoretical countermeasure to gerrymandering short of proportional representation is the bureaucratic alternative: nonpartisan districting. This has been used with success in a few states ${ }^{64}$ but has not been popular in state legislatures because it delegates a function of supreme importance to the legislators for its heavy bearing on their continuance in office. Such matters are deemed too important to entrust to functionaries. Courts could treat this problem in one of two ways, neither of which is very satisfactory: they could treat legislative redistricting as "inherently unequal," a reasonable assumption in most cases where one party or group controls the legislature, but with highly disruptive implications if extended to other acts of the same legislature which are likewise partisan and expected to be so; alternatively, courts could draw their own districts, a practice which they have hitherto tried to avoid because of the political sensitivity of the task. These bureaucratic judicial alternatives raise two further considerations: the immediate recognition that courts and commissions are not necessarily nonpartisan, ${ }^{65}$ and the larger question of whether commitment of a problem to nonrepresentative bodies can be properly regarded as a revitalization of representative government.

The reapportionment cases have revitalized representative government only in the sense that amputating someone's leg and replacing it with a wooden leg "revitalizes" the leg; the Court's logic of inter-

63 Or produce a disruptive redistricting with every change in party ascendancy at the polls.

64 See note 56 supra.

65 See second paragraph, note 56 supra. 
vention started from the assumption that the states' existing institutions were not worth saving (except in Oregon, the one state that met the Court's standards before 1962). The Court in Baker v. Carr ${ }^{60}$ discarded the alternative of nonintervention; in the Reapportionment Cases ${ }^{67}$ it discarded the alternative of selective intervention, of attempting to distinguish between states like Alabama which needed wooden legs and states like Colorado that did not. Reapportionists have argued that every state needs equal districts, essentially because they are more equal than unequal ones, but such arguments assume their own conclusion; they prove, in effect, that every state needs wooden legs because they are more wooden than any other kind. The Supreme Court has bought this logic, why and at what cost or profit to itself I have examined elsewhere, ${ }^{68}$ but the cost to representative government in the states, while it cannot be measured, seems in most cases very high. Equal districts have chopped up some communities and stuck the pieces onto others; unqualified by any attempt to consider more subtle forms of structural bias like bloc voting, strategic majorities, multi-member districts, and gerrymanders, they can and have aggravated such biases by taking away the most workable form of counter balance; they often jar with geographical needs; if strictly applied at the local level they can discourage attempts to settle local problems through representative channels; radical district changes are enormously disruptive to other forms of legislation and highly productive of gerrymanders and discriminatory multi-member districts; and imposing a rigid rule on people who do not want it, ${ }^{69}$ however dressed up with democratic rhetoric, is not democratic. Arthur Sutherland has expressed as well as anyone the rationale for entrusting the Justices with powers not given to other men: they are supposed to be educated, experienced, practical men.

To make inevitable distinctions between a time for judicial

66369 U.S. 186 (1962).

67 Gray v. Sanders, 372 U.S. 368 (1963); Wesberry v. Sanders, 376 U.S. 1 (1964); Reynolds v. Sims, 377 U.S. 533 (1964); WMCA, Inc. v. Lomenzo, 377 U.S. 633 (1964); Maryland Comm. for Fair Representation v. Tawes, 377 U.S. 656 (1964); Davis v. Mann, 377 U.S. 678 (1964); Roman v. Sincock, 377 U.S. 695 (1964); Lucas v. Colorado Gen. Assembly, 377 U.S. 713 (1964).

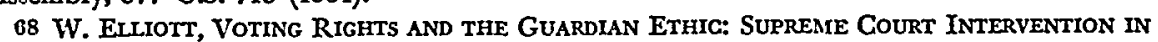
Voting Rights Disputes from Tanex to WarRen, ch. 7 (to be published).

60 In Lucas v. Forty-fourth Gen. Assembly, 377 U.S. 713 (1964) the Court overruled a 2-1 popular majority opposed to equal districts in the Colorado Senate, and Colorado was not an isolated case. More often than not, the public matched or surpassed their elected representatives' hostility to reapportionment. Initiative proposals favoring urban voters in several urban states-Michigan 1924, 1930, 1932, 1952; Colorado and Washington, 1962; California, 1926, 1928, 1948, 1960, 1962-were resoundingly defeated amid grumblings by political scientists that "citizens should be given the blessings of equality whether they want them or not." 
action and a time for judicial self-restraint, few sources of guidance can be as satisfactory as the disciplined prepossessions of an independent judge, aware of history, tolerant of the democratic process, and conscious of human limitations. ${ }^{70}$

But this rationale is good only as long as the Justices do not bungle. In the reapportionment cases, the majority's awareness of history took the form of wholesale fabrication; they "tolerated" the democratic process by overruling it; and their consciousness of human limitations did not stop them from imposing their own distorted and incomplete version of representative government upon the states. The Reapportionment Revolution does represent a triumph of administrative policy in the sense that it had fitted almost every state with wooden legs in the space of only a few years, but it is a triumph of Equal Representation for Equal Numbers only if you like wooden legs-and that must be regarded (as Andrew Hacker told us in 1965) as a question of aesthetics.

\footnotetext{
70 Sutherland, Establishment According to Engel, 76 HARv. L. REv. 25, 40 (1962).
} 